\author{
ФОРМУВАННЯ ПЕРЕДУМОВ РОЗВИТКУ ЗОВНІШНЬОЕКОНОМІЧНОЇ \\ ДІЯЛЬНОСТІ СІЛЬСЬКОГОСПОДАРСЬКИХ ПІДПРИЄМСТВ УКРАЇНИ \\ FORMATION OF BACKGROUND FOR DEVELOPMENT OF FOREIGN \\ ECONOMIC ACTIVITIES OF AGRICULTURAL ENTERPRISES OF UKRAINE
}

Удк 339.5:633:334.72

https://doi.org/10.32843/bses.49-8

\section{Білянський ю.О.}

здобувач кафедри менеджменту,

публічного управління

та адміністрування

Подільський державний

аграрно-технічний університет

Bilianskyi Yurii

State Agrarian and Engineering University in Podilia

\begin{abstract}
у статті досліджено наявні передумови, що привели до зміни в експортно-імпортних потоках основних видів сільськогосподарської продукції та продовольства, зрушення у товарній структурі експорту аграрноі продукції з України щодо глибини ії переробки. Визначено напрями, що сприятимуть підвищенню ефективності господарювання аграрних товаровиробників та збільшенню їх присутності в експортних операціях із сільськогосподарською продукцією. Розглянуто економічні передумови, на прикладі підприємств ТОВ СП «Нібулон» та МХП висвітлено можливості сільськогосподарських підприємств у здійсненні експортноімпортних операцій. Запропоновано низку заходів державної підтримки у здійсненні експорту власної продукції вітчизняними аграрними підприємствами, до яких належать консалтинговий супровід, інсрормаційно-аналітичне забезпечення, залучення інвестичійних ресурсів у межах державно-приватного партнерства.

Ключові слова: експорт, імпорт, сільськогосподарська продукція, світовий ринок, внутрішній ринок, ціна, сільськогосподарські підприємства.
\end{abstract}

В статье исследованы существующие предпосылки, которые привели к изме- нению в экспортно-импортных потоках основных видов сельскохозяйственной продукции и продовольствия, сдвиги в товарной структуре экспорта аграрной продукции из Украины касательно глубины ее переработки. Определены направления, которые будут способствовать повышению эфффективности хозяйствования аграрных товаропроизводителей и увеличению их присутствия в экспортных операциях с сельскохозяйственной продукцией. Рассмотрены экономические предпосылки, на примере предприятий ООО $\mathrm{C}$ «Нибулон» и МХП освещены возможности сельскохозяйственных предприятий в осуществлении экспортно-импортных операций. Предложен ряд мер государственной поддержки в осуществлении экспорта собственной продукции отечественными аграрными предприятиями, к которым относятся консалтинговое сопровождение, инсрормационно-аналитическое обеспечение, привлечение инвестиционных ресурсов в пределах государственно-частного партнерства.

Ключевые слова: экспорт, импорт, сельскохозяйственная продукция, мировой рынок, внутренний рынок, чена, сельскохозяйственные предприятия.

The article explores the existing conditions that have contributed to Ukraine's entry and consolidation in the world food markets. There is established that due to the existing natural and resource potential, combined with the favorable conditions of the world market and the development of an appropriate institutional environment, our country has succeeded in gaining a leading position in the foreign markets of grain and oilseeds. The problems of development of foreign economic activity of agricultural enterprises are outlined. The author attributes to them the fact that domestic agricultural exports are of raw material character, that is, mainly crop products are exported without deep processing. As well as the low presence of direct producers in export operations with agricultural products. There is established that agricultural producers are practically not engaged in import activities. The directions that will help to increase the efficiency of management of agricultural producers and increase their activity in foreign economic transactions with agricultural products are determined. The economic conditions that led to changes in the export-import flows of the main types of agricultural products and food, shifts in the commodity structure of export of agricultural products from Ukraine in terms of the depth of its processing are considered. On the example of the enterprises of JV Nibulon LLC and MHP the possibilities of agricultural enterprises in carrying out export-import operations are highlighted. The author has proved that the development of foreign economic activity of agricultural enterprises should be carried out in the conditions of formation of appropriate institutional support, which involves the use of a complex of instruments of assistance from the state. A number of measures of state support for export of own products by domestic agrarian enterprises are proposed, which include providing consulting support for export operations, information and analytical support in order to increase the efficiency of finding a niche in the world market, attracting investment resources within the framework of public-private partnership production of niche products that are in demand on the world market.

Key words: export, import, agricultural products, world market, domestic market, price, agricultural enterprises.

Постановка проблеми. Сьогодні поглиблення міжнародних інтеграційних процесів створюють нові можливості для розвитку зовнішньоекономічної діяльності вітчизняних сільськогосподарських підприємств. Передумови цього формуються під впливом фракторів світового ринку та залежать від наявності внутрішніх можливостей України. Кон'юнктура світового ринку та зростаючий попит на енергетичні й продовольчі ресурси створили сприятливі передумови нарощування вітчизняного експорту насіння зернових, олійних культур.
Наша держава має великий природно-ресурсний потенціал, вдале геограсрічне розміщення, що дають можливість аграрним підприємствам реалізовувати конкурентні переваги власної продукції на світовому ринку. Проте вважаємо, що вони в сучасних умовах розвитку інституційного середовища використані далеко не повністю. Нові умови господарювання, світові тенденції у фрормуванні попиту на енергетичні й продовольчі ресурси вимагають розширення експортної орієнтації аграрних підприємств України, диверсифрікації їх виробничої 
та експортної діяльності, що загалом визначатиме ефективність позиціонування нашої держави на світовому ринку.

Аналіз останніх досліджень і публікацій. Проблематика зовнішньоекономічної діяльності аграрних підприємств є досить актуальною серед науковців. Дослідженням 3 пошуку можливостей їх розвитку через реалізацію експортних можливостей приділили увагу такі економісти-аграрники, як Н.А. Карасьова [1], С.М. Кваша [2], В.М. Онегіна [3], Т.О. Осташко [4], Н.І. Патика [5], А.Л. Педорченко [6], М.І. Пугачов [7], О.М. Шпичак [8]. У зв'язку із сучасними викликами, що виникають у результаті подальшого розвитку світової торгівлі, зміною вектору розвитку вітчизняної зовнішньої політики України, зростаючої конкуренції між учасниками світового та внутрішнього ринків існує потреба поглиблення наукових досліджень у напрямі пошуку можливостей для фрормування сприятливого середовища розвитку зовнішньоекономічної діяльності сільськогосподарських підприємств.

Постановка завдання. Метою дослідження $€$ вивчення наявних передумов розвитку зовнішньоекономічної діяльності вітчизняних сільськогосподарських підприємств, що сприяли виходу та укріпленню України на світових ринках продовольства, а також визначення напрямів, що сприятимуть підвищенню ефективності господарювання аграрних товаровиробників та збільшенню їх присутності в експортних операціях із сільськогосподарською продукцією.

Виклад основного матеріалу дослідження. Дослідження підтверджують, що зовнішньоекономічна діяльність сільськогосподарських підпри- ємств спрямована переважно на експорт виробленої продукції. Меншою мірою вона має імпортний характер. Імпорт здійснюється здебільшого для забезпечення ресурсами для виробничого процесу. Розглянемо наявні передумови реалізації експортної діяльності сільськогосподарських підприємств.

Наявний значний експортний потенціал в аграрному секторі України сорормувався за рахунок високої родючості вітчизняних сільськогосподарських земель, сприятливого географічного розташування, зокрема довгої лінії узбережжя України та вдалого розташування відносно країн Близького Сходу, Західної Європи та Азії, що $є$ основними споживачами цієї продукції, наявності глибоководних портів, компактності країни, що зумовлює тривалість терміну доставки експортних вантажів залізницею протягом 3-5 днів тощо.

Всі ці передумови разом зі зростаючим попитом на світовому ринку продовольства та сировинних сільськогосподарських товарів зумовили нарощення темпів експортної діяльності та зміни в експортно-імпортних співвідношеннях на ринках окремих видів аграрної продукції (табл. 1). Слід відзначити також, що ці процеси відбувалися під впливом суттєвих змін в інституційному забезпеченні зовнішньоекономічної діяльності та вектору торговельної політики держави із зовнішніми партнерами, зокрема в результаті підписання низки міжнародних торговельних угод і договорів, які стосуються співробітництва 3 країнами ЄС, а також вступу до Світової організації торгівлі. Дослідження змін в експортно-імпортних потоках протягом 2004-2018 років свідчать про суттєве збільшення обсягів експорту продукції зерна

Таблиця 1

Зміни в експортно-імпортних потоках основних видів сільськогосподарської продукції та продовольства через призму внутрішнього ринку протягом 2004-2018 років

\begin{tabular}{|c|c|c|c|c|}
\hline Вид продукції & $\begin{array}{c}\text { Обсяг експорту, } \\
\text { тис. т }\end{array}$ & $\begin{array}{c}\text { Обсяг імпорту, } \\
\text { тис. т }\end{array}$ & $\begin{array}{l}\text { Частка експорту у } \\
\text { виробництві, \% }\end{array}$ & $\begin{array}{c}\text { Частка імпорту у фонді } \\
\text { споживання, \% }\end{array}$ \\
\hline \multicolumn{5}{|c|}{2018 рік } \\
\hline Зерно & 42940 & 280 & 61,3 & 5,0 \\
\hline Овочі & 434 & 188 & 4,4 & 2,7 \\
\hline Олія & 5986 & 259 & 95,9 & 51,7 \\
\hline Плоди & 331 & 878 & 10,9 & 35,9 \\
\hline Молоко & 807 & 180 & 8,0 & 2,2 \\
\hline М'ясо & 399 & 283 & 16,9 & 12,7 \\
\hline Яйця & 186 & 4 & 20,0 & 0,6 \\
\hline \multicolumn{5}{|c|}{2018 рік до 2004 року (\%; +, - в. п.) } \\
\hline Зерно & 5,5 рази & 32,0 & 42,7 & $-9,7$ \\
\hline Овочі & 5,1 рази & 4,2 рази & 3,2 & 1,9 \\
\hline Олія & 6,7 рази & 98,1 & 33,3 & 10,1 \\
\hline Плоди & 1,6 рази & 2,7 рази & 0,5 & 15,4 \\
\hline Молоко & 38,0 & 2,2 рази & $-7,5$ & 1,4 \\
\hline М'ясо & 3,6 рази & 77,3 & 10,1 & $-7,4$ \\
\hline Яйця & 186 разів & 100 & 19,8 & $-0,1$ \\
\hline
\end{tabular}

Джерело: складено автором за даними Державної служби статистики України 
(у 5,5 разів) та олії (у 6,7 разів). Частка експорту цих видів продукції у їх внутрішньому виробництві складає 61\% та 96\% відповідно. Також має місце позитивна тенденція збільшення обсягів експорту продукції, для виробництва якої необхідно використовувати зерно. Зокрема, це м'ясо та яйця, експортні потоки яких протягом досліджуваного періоду збільшились у 3,6 та 186 разів відповідно. У 2018 році вони складали 17\% та 20\% від виробництва всередині країни.

Такі тенденції сформувалися за рахунок підприємств, що займаються виробництвом яєць та м'яса курей. Встановлено, що мають місце позитивні тенденції у заміщенні імпорту вітчизняною продукцією за такими видами, як зерно, цукор, м'ясо та яйця, де зміна частки імпорту у фонді споживання населенням складала від 0,1\% до 9,7\%. Суттєво збільшилися обсяги імпорту овочів, плодів та молока, а саме у 4,2; 2,7 та 2,2 рази відповідно, що також зумовило збільшення його частки у споживанні всередині країни. Саме за рахунок цих видів продукції та продуктів їх переробки сільськогосподарські підприємства сьогодні мають можливість розвивати свою експортну діяльність.

Дослідження змін в експортно-імпортних потоках зерна у видовому зрізі свідчить про те, що нарощення експорту відбулося за рахунок кукурудзи (табл. 2). Обсяги цього виду продукції, які були вивезені за межі країни у 2018 році, у 17 разів більше порівняно з 2004 роком. Слід відзначити, що зменшився експорт нішевих видів зернових, зокрема проса та вівса, незважаючи на те, що ціна на ці види продукції зросла значно більше порівняно з іншими. Це розкриває перспективні напрями розвитку зовнішньоекономіч ної діяльності для безпосередніх виробників цих видів продукції.
Порівняно 3 експортом зерна обсяги його імпорту $€$ незначними, переважно завозиться в Україну кукурудза для забезпечення сільськогосподарських підприємств насіннєвим матеріалом. Частка насіннєвої кукурудзи у загальному обсязі імпорту у 2018 році складала 96\%. Також структура імпорту фрормується з продовольчого зерна пшениці твердих сортів, рису та гречки.

Встановлено, що наявні тенденції у структурі експортних потоків сфрормувалися в результаті створення конкурентних переваг тих чи інших видів сільськогосподарської продукції (табл. 3).

Досліджено рівень конкурентоспроможності експортно орієнтованих видів вітчизняної сільськогосподарської продукції (пшениці, ячменю, кукурудзи, соняшникової олії, ріпаку, соєвих бобів) на світовому ринку за допомогою відносних показників конкурентоспроможності, зокрема індексу відносної експортної конкурентоспроможності (RCA), індексу відносної залежності від імпорту (RMP), індексу відносних торговельних переваг (RTA) протягом 2010-2017 років. Динаміка змін показника RCA свідчить про зростання відносної експортної конкурентоспроможності за такими видами продукції, як пшениця, кукурудза та соєві боби. Значення індексу відносних торговельних переваг свідчить про те, що найбільш конкурентоспроможними видами продукції протягом досліджуваного періоду була соняшникова олія (у 2017 році RTA становить 31,6), ячмінь $(8,0)$ та кукурудза $(6,4)$. Проте спостерігається знижувальна тенденція індексу RTA, зокрема щодо ячменю він зменшився у 2,5 рази, щодо соняшникової олії майже в 1,5 рази.

Дослідження свідчать про те, що реалізація вищевикладених можливостей України в експорті сільськогосподарської продукції меншою мірою

Таблиця 2

Тенденції в експорті та імпорті зерна за основними видами

\begin{tabular}{|c|c|c|c|c|c|c|}
\hline \multirow{2}{*}{ Вид продукції } & \multicolumn{2}{|c|}{2004 рік } & \multicolumn{2}{|c|}{2018 рік } & \multicolumn{2}{|c|}{$\begin{array}{l}\text { Відношення } 2018 \text { року } \\
\text { до } 2004 \text { року (\%, разів) }\end{array}$} \\
\hline & $\begin{array}{c}\text { Кількість, } \\
\text { тис т }\end{array}$ & $\begin{array}{l}\text { Ціна, дол } \\
\text { США за } 1 \text { т }\end{array}$ & $\begin{array}{c}\text { Кількість, } \\
\text { тис т }\end{array}$ & $\begin{array}{c}\text { Ціна, дол } \\
\text { СшА за } 1 \text { т }\end{array}$ & Кількість & Ціна \\
\hline \multicolumn{7}{|c|}{ Експорт } \\
\hline Пшениця & 2553,9 & 113,1 & 16373,4 & 183,5 & 6,4 рази & 162 \\
\hline Ячмінь & 3710,4 & 99,9 & 3597,5 & 189,5 & 97 & 190 \\
\hline Кукурудза & 1233,9 & 136,9 & 21434,4 & 163,6 & 17 разів & 120 \\
\hline Просо & 33,5 & 114,8 & 25,2 & 311,9 & 75 & 2,7 рази \\
\hline Овес & 22,6 & 95,1 & 8,1 & 218,1 & 36 & 2,3 рази \\
\hline \multicolumn{7}{|c|}{ Імпорт } \\
\hline Пшениця & 593,2 & 185,6 & 4,0 & 694,7 & 0,7 & 3,7 рази \\
\hline Ячмінь & 23,7 & 215,1 & 7,4 & 333,1 & 31,2 & 155 \\
\hline Кукурудза & 14,0 & 1695,0 & 37,4 & 3813,2 & 2,7 рази & 2,3 рази \\
\hline Рис & 102,3 & 253,0 & 86,5 & 444,9 & 84,6 & 176 \\
\hline Гречка & 0,1 & 234,9 & 11,5 & 200,2 & 115 разів & 85 \\
\hline
\end{tabular}

Джерело: складено автором за даними Державної митної служби України 
Індекси виявлених переваг для окремих видів вітчизняної сільськогосподарської продукції та продуктів її переробки на світовому ринку

\begin{tabular}{|c|c|c|c|c|c|c|}
\hline Рік & Ячмінь & Кукурудза & Пшениця & Соняшникова олія & Ріпак & Соєві боби \\
\hline \multicolumn{7}{|c|}{ RCA } \\
\hline 2010 & 20,47 & 3,21 & 3,38 & 45,21 & 9,30 & 0,25 \\
\hline 2017 & 8,1 & 8,0 & 5,6 & 31,6 & 6,1 & 1,4 \\
\hline \multicolumn{7}{|c|}{$R T A$} \\
\hline 2010 & 20,38 & 2,17 & 3,38 & 45,14 & 8,48 & 0,24 \\
\hline 2017 & 7,99 & 6,42 & 5,59 & 31,56 & 5,04 & 1,41 \\
\hline \multicolumn{7}{|c|}{$R M P$} \\
\hline 2010 & 0,09 & 1,04 & 0,01 & 0,07 & 0,81 & 0,01 \\
\hline 2017 & 0,10 & 1,55 & 0,03 & 0,00 & 1,08 & 0,04 \\
\hline
\end{tabular}

Джерело: складено автором за даними ФАО

забезпечується за рахунок діяльності безпосередньо її виробників та здійснюється переважно трейдерами. Проте частка сільськогосподарських підприємств в експорті протягом останніх років збільшилась. Це відбулося за рахунок великих сільськогосподарських товаровиробників. Наприклад, ТОВ СП «Нібулон» має земельний банк у розмірі 80 тис. га, а у його структурі понад 90\% займають посіви зернових та олійних культур. Підприємство завдяки власній інфрраструктурі перевантажувальних терміналів та комплексів 3 приймання, зберігання й відвантаження здійснює експорт цих культур. Згідно з оцінками експертів частка підприємства у загальному обсязі експорту з країни складає близько 10\%. Найбільшу частку у структурі експорту сільськогосподарського підприємства «Нібулон» мають пшениця та кукурудза (40,8\% та 42,9\% відповідно). Геограсрічна спрямованість експорту охоплює країни ЄС та країни Близького й Далекого Сходу. Одним з напрямів створення передумов для розвитку його зовнішньоекономічної діяльності на ринку аграрної продукції є розбудова внутрішньої логістики, зокрема, річкових вантажоперевезень. Частка перевезень водним транспортом у загальних обсягах транспортування сільськогосподарської продукції складає близько 60\%. Імпортна діяльність підприємства забезпечує фрормування матеріально-технічної бази. Зокрема, цим є укладення зовнішньоекономічних контрактів на поставки імпортного обладнання для розбудови перевантажувальних річкових терміналів та закупівлі дизельного пального за кордоном [9].

На ринку м'яса курей одним із найбільших експортерів є ПРАТ «Миронівський хлібопродукт», який $€$ вертикально інтегрованим підприємством із закритим циклом. В його складі є сільськогосподарські підприємства, що займаються виробництвом сировини для кормів та птахофабрики, продукція яких спрямовується на експорт. Це підприємство експортує власну продукцію в країни $€ C$, Близького Сходу, Африки. Для забезпечення власною кормовою базою підприємство сорормувало земельний банк близько 370 тис. га. [10].

В результаті висвітлених вище змін відбулися зрушення в товарній структурі експорту аграрної продукції з України щодо глибини її переробки (рис. 1).

Загалом частка аграрного експорту протягом 2004-2014 років зросла з 10,6\% до 39,3\%, що свідчить про зростаюче значення експортної діяльності для сільськогосподарських товаровиробників. Однак дослідження свідчать про чітку тенденцію до збільшення частки продукції, що $€$ сировиною або має незначний ступінь переробки, продукції, під час виробництва якої має місце високий рівень механізації та автоматизації із залученням значних земельних ресурсів. Зокрема, частка валютних надходжень від експорту зерна протягом 2004-2018 років збільшилась на 15 в. п., насіння олійних культур - 6 відсоткових пунктів, тоді як частка експорту готових продуктів харчування, молока та молокопродуктів знизилась на 17 та 10 відсоткових пунктів відповідно. Позитивна тенденція має місце щодо експорту соняшникової олії, частка рослинних олій у структурі експорту збільшилась на 8 відсоткових пунктів. Таким чином, сьогодні аграрний експорт має сировинний характер.

Структура імпорту аграрної продукції протягом досліджуваного періоду суттєво не змінилася. Зменшилася частка готових продуктів на 7 відсоткових пунктів, що свідчить про позитивну динаміку імпортозаміщення продовольства.

Висновки 3 проведеного дослідження. Результати дослідження наявних передумов розвитку зовнішньоекономічної діяльності вітчизняних сільськогосподарських підприємств свідчать про те, що завдяки наявному природному й ресурсному потенціалу разом зі сприятливою кон'юнктурою світового ринку та розвитком відповідного інституційного середовища нашій країні вдалося завоювати провідні позиції на зовнішніх ринках зерна та насіння олійних культур. Проте тут 


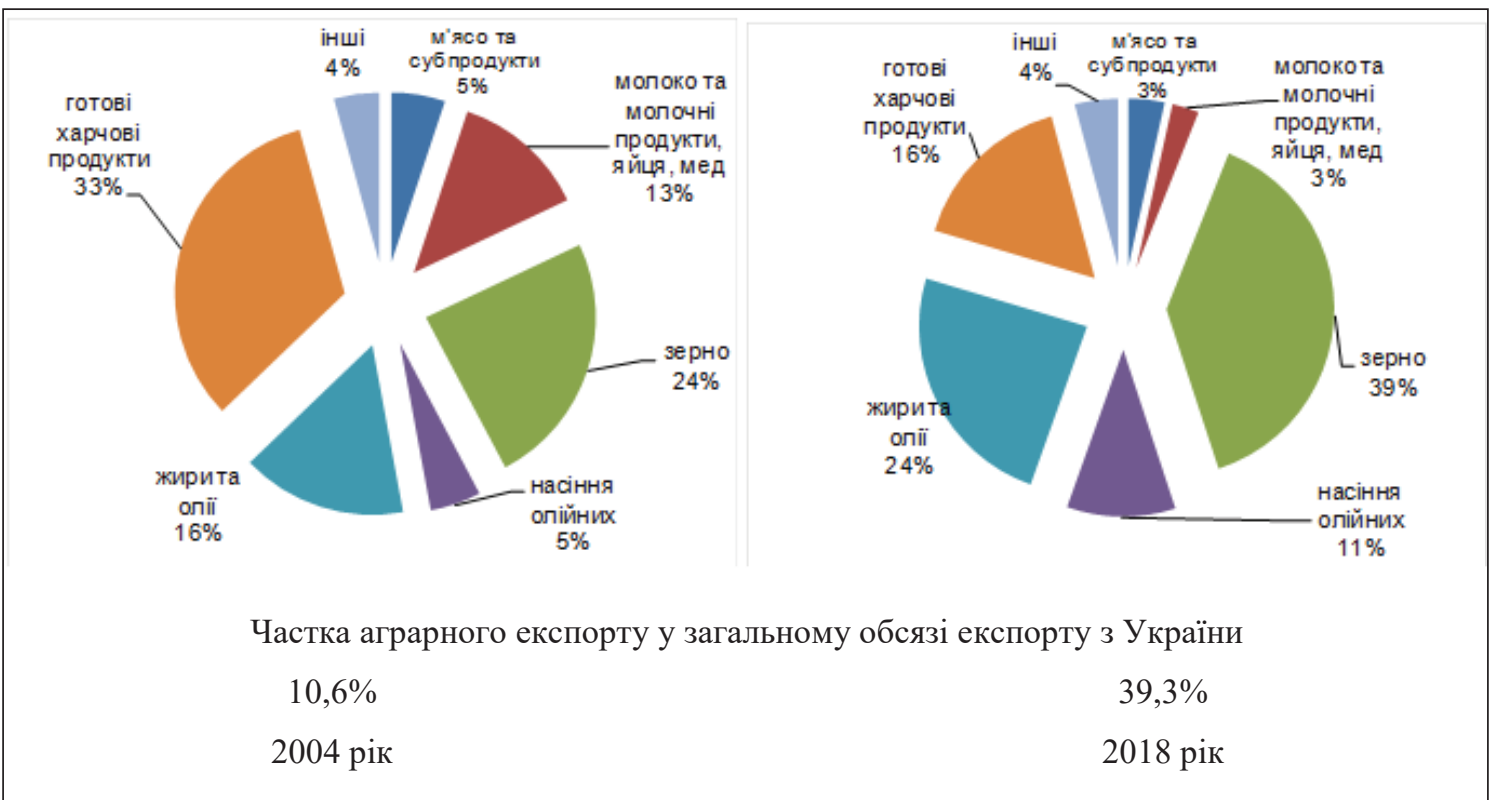

Рис. 1. Порівняння структури експорту сільськогосподарської продукції та продуктів її переробки

Джерело: складено автором за даними Державної митної служби України

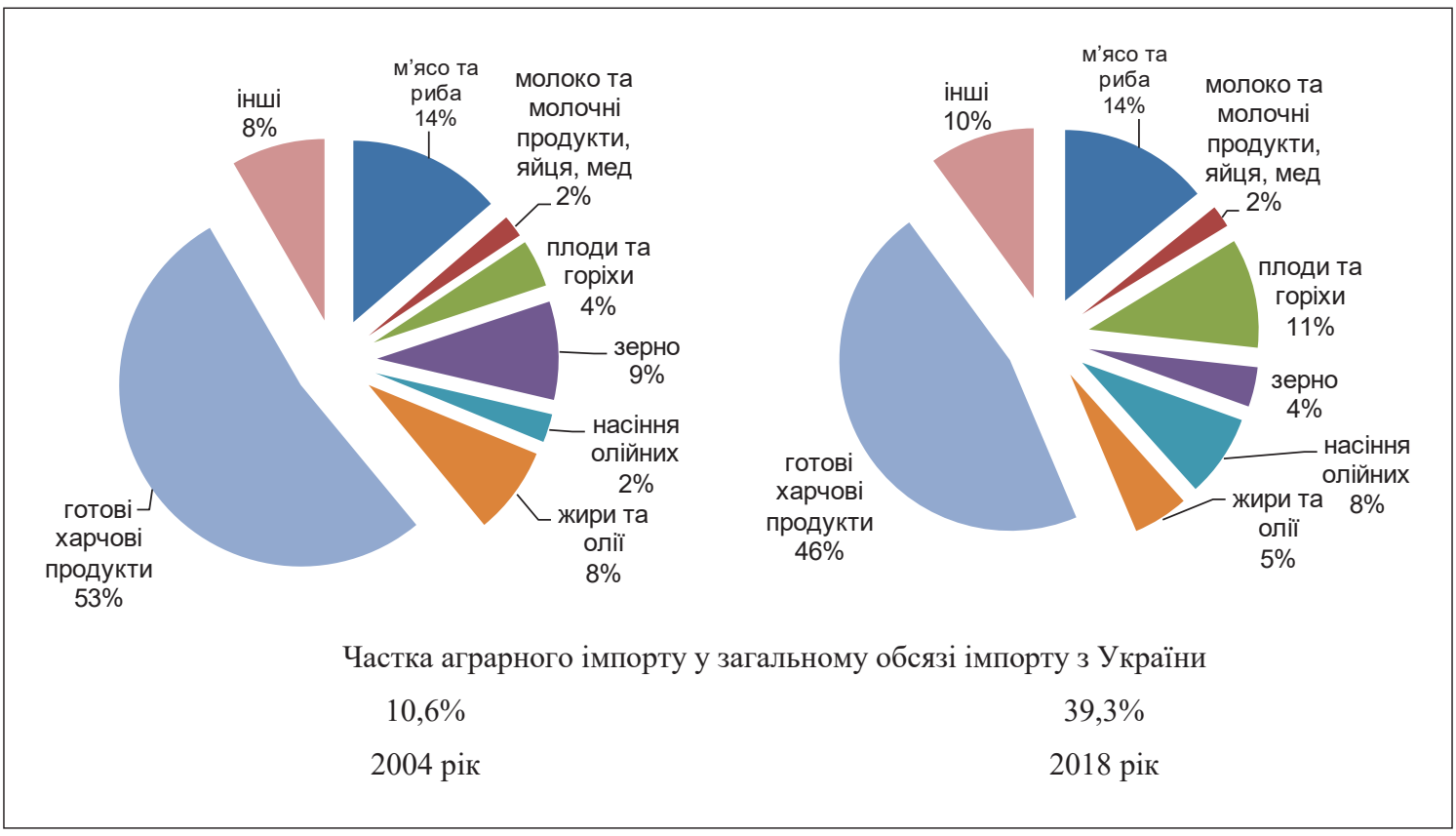

Рис. 2. Порівняння структури імпорту сільськогосподарської продукції та продуктів ії переробки

Джерело: складено автором за даними Державної митної служби України

існує низка проблем, які потребують вирішення. По-перше, вітчизняний аграрний експорт має сировинний характер, тобто вивозиться переважно рослинницька продукція без глибокої переробки. По-друге, присутність безпосередніх виробників у експортних операціях із сільськогосподарською продукцією є незначною. За рідкісним винятком сільськогосподарські товаровиробники не займа- ються імпортною діяльністю. Розвиток зовнішньоекономічної діяльності сільськогосподарських підприємств, на нашу думку, повинен здійснюватися в умовах фрормування відповідного інституційного забезпечення, яке передбачає використання комплексу інструментів сприяння з боку держави. Вони мають передбачати заходи підтримки щодо здійснення власного експорту аграрними підпри- 
ємствами, надання консалтингового супроводу експортних операцій, інорормаційно-аналітичного забезпечення задля підвищення ефективності пошуку ніші на світовому ринку, залучення інвестиційних ресурсів у межах державно-приватного партнерства для диверсифікації діяльності та виробництва нішевих видів продукції, які користуються попитом на світовому ринку.

\section{БІБЛІОГРАФІЧНИЙ СПИСОК:}

1. Карасьова Н.А. Експортоорієнтована діяльність аграрного сектора в умовах глобалізації світової економіки. Житомир : Полісся, 2016. 256 с.

2. Кваша С.М. Експорт та імпорт продукції агарного сектору України: стан та тенденції. Київ : ННЦ IAE, 2013. $80 \mathrm{c}$.

3. Онегіна В.М., Білецький О.В. Цінові ризики експортної орієнтації сільськогосподарського виробництва. Вісник Харківського національного технічного університету сільського господарства. Економічні науки. 2019. Вип. 200. С. 54-61.

4. Осташко Т.О. Експорт агропродовольчих товарів у ЄС: перспективи і завдання. Економіка і прогнозування. 2016. № 1. С. 83-93.

5. Патика Н.І. Конкурентоспроможність сільського господарства України: глобальний та національний вимір. Вінниця : ТОВ «Твори», 2019. 368 с.

6. Педорченко А.Л. Формування конкурентних переваг товаровиробників-експортерів олійних культур. Ефрективна економіка. 2015. № 2. URL: http:// www.economy.nayka.com.ua/?op=1\&z=3819 (дата звернення: 21.01.2020).

7. Пугачов М.І., Мельник А.О. Інтеграційні альтернативи для АПК України в умовах світової економічної кризи. Економіка АПК. 2014. № 4. С. 28-31.

8. Шпичак О.М., Боднар О.В., Шпичак О.О. Теоретико-методологічні та практичні основи ціноутворення : монографрія. Київ : ЦП «Компринт», 2017. 545 c.

9. Зовнішньоекономічна діяльність. Нібулон. URL: https://www.nibulon.com/data/pro-kompaniyu/ napryamki-diyalnosti/zovnishnoekonomichna-diyalnist. html (дата звернення: 17.01.2020).

10. Птахівництво. Миронівський хлібопродукт. URL: https://www.mhp.com.ua/uk/operations/poultry (дата звернення: 21.01.2020).

\section{REFERENCES:}

1. Karasova N.A. (2016). Eksportooriientovana diialnist ahrarnoho sektora $v$ umovakh hlobalizatsii svitovoi ekonomiky [Export-oriented activity of agrarian sector in the conditions of globalization of the world economy]. Zhytomyr : Polissia (in Ukrainian).

2. Kvasha S.M. (2013). Eksport ta import produktsii aharnoho sektoru Ukrainy: stan ta tendentsii [Export and Import of Agar Products in Ukraine: Status and Trends]. Kyiv : NNC IAE (in Ukrainian).

3. Onehina V.M., Biletskyi O.V. (2019) Tsinovi ryzyky eksportnoi oriientatsii silskohospodarskoho vyrobnytstva [Price risks of export orientation of agricultural production] Visnyk Kharkivskoho natsionalnoho tekhnichnoho universytetu silskoho hospodarstva. Ekonomichni nauky, vol. 200, pp. 54-61.

4. Ostashko T.O. (2016) Eksport ahroprodovolchykh tovariv u YeS: perspektyvy i zavdannia [Export of agrifood products to the EU: prospects and tasks. Economics and forecasting]. Ekonomika i prohnozuvannia, no. 1, pp. 83-93.

5. Patyka N.I. (2019) Konkurentospromozhnist silskoho hospodarstva Ukrainy: hlobalnyi ta natsionalnyi vymir [Competitiveness of Ukrainian agriculture: a global and national dimension]. Vinnytsia : TOV "Tvory".

6. Pedorchenko A.L. (2015) Formuvannia konkurentnykh perevah tovarovyrobnykiv-eksporteriv oliinykh kultur [Formation of competitive advantages of oilseed exporters]. Efektyvna ekonomika. 2. Available at: http://www.economy.nayka.com.ua/?op=1\&z=3819 (accessed: 21 January 2020).

7. Puhachov M.I., Melnyk A.O. (2014) Intehratsiini alternatyvy dlia APK Ukrainy v umovakh svitovoi ekonomichnoi kryzy [Integration alternatives for agroindustrial complex of Ukraine in the conditions of the world economic crisis]. Ekonomika APK, 4, pp. 28-31.

8. Shpychak O.M., Bodnar O.V., Shpychak O.O. (2017) Teoretyko-metodolohichni ta praktychni osnovy tsinoutvorennia [Theoretical, methodological and practical bases of pricing]. Kyiv : Komprint (in Ukrainian).

9. Zovnishnoekonomichna diialnist [Foreign economic activity]. Nibulon. Available at: https:// www.nibulon.com/data/pro-kompaniyu/napryamki-diyalnosti/zovnishnoekonomichna-diyalnist.html (accessed 17 January 2020).

10. Ptakhivnytstvo [Poultry farming] Myronivskyi khliboprodukt. Available at: https://www.mhp.com.ua/uk/ operations/poultry (accessed 21 January 2020). 